\title{
Monitorowanie zachowań osób skazanych za przestępstwa na tle seksualnym
}

\author{
Piotr Herbowski \\ ORCID: 0000-0002-7736-3614 \\ Katedra Prawa Publicznego i Teorii Prawa \\ Wydział Psychologii i Prawa w Poznaniu \\ SWPS Uniwersytet Humanistycznospołeczny
}

\section{DOMINIKA SŁAPCZYŃSKA}

Polskie Stowarzyszenie Poligraferów

\section{Bezpieczeństwo publiczne}

Zapewnienie bezpieczeństwa obywatelom jest niewątpliwie jednym z podstawowych celów działalności państwa. Zostało to wprost wyrażone w art. 5 Konstytucji Rzeczypospolitej Polskiej ${ }^{1}$. Należy przez to rozumieć przeciwdziałanie wszelkim bezprawnym zagrożeniom oraz zamachom, które są wymierzone w funkcjonowanie obywateli. Reakcja służb państwowych może mieć również charakter profilaktyczny wobec rzeczywistych lub potencjalnych, choć realnych zagrożeń i zamachów ${ }^{2}$. Przestępczość na tle seksualnym jest z pewnością takim realnym zagro-

${ }^{1}$ Dz.U. z 1997 r. Nr 78, poz. 483 z późn. zm.

2 Uzasadnienie wyroku Trybunału Konstytucyjnego z dnia 23 czerwca 2009 roku w sprawie K 54/07, OTK ZU 2009, nr 6A, poz. 86. 
żeniem, które uznawane jest za stwarzające konieczność podjęcia działań zmierzających do przeciwdziałania jego powstawaniu.

Jak więc zapewnić bezpieczeństwo publiczne przez efektywne monitorowanie osób skazanych za przestępstwa seksualne? Aby odpowiedzieć na to pytanie i wyciągnąć wnioski na przyszłość, najpierw trzeba ocenić dotychczasową praktykę i podejmowane przez instytucje państwowe działania kontrolne mające służyć zapobieganiu temu dewiacyjnemu zjawisku społecznemu. Konieczne jest także ustalenie, czy organy te interesują się sprawcami, u których zdiagnozowano zaburzenia preferencji seksualnych.

\section{Czy zaburzenia preferencji seksualnych można wyleczyć?}

Istotnym założeniem towarzyszącym rozważaniom będzie przeważające $\mathrm{w}$ nauce stanowisko $^{3}$, że ze względu na charakter zaburzeń preferencji seksualnych nie da się ich wyleczyć w sensie medycznym ${ }^{4}$, a co

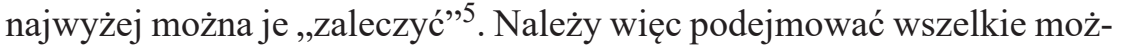
liwe działania, aby ograniczyć wpływ tych zaburzeń na zachowania osób nimi dotkniętych ${ }^{6}$.

\section{Dotychczasowe rozwiązania służące monitorowaniu zachowań osób skazanych za przestępstwa seksualne}

A. Sakowicz w opinii prawnej na temat projektu ustawy o przeciwdziałaniu zagrożeniom przestępczością na tle seksualnym, który wprowadzał Rejestr Sprawców Przestępstw na Tle Seksualnym, wskazał, że:

${ }^{3}$ A. Strzelec, Przymusowe leczenie sprawców czynów zabronionych popetnionych w zwiazku z zaburzeniami preferencji seksualnych, [w:] Konteksty prawa i praw człowieka, red. Z.M. Dymińska, Kraków 2012, s. 59.

${ }^{4}$ J.K. Gierowski, Uwagi psychologa sadowego o nowych regulacjach prawnych w sprawach o tzw. przestępstwa seksualne, „Psychiatria Polska” 46, 2012, nr 1, s. 11-12; K. Pospiszyl, Przestęstwa seksualne. Geneza, postacie, resocjalizacja oraz zabezpieczenia przed powrotnościq, Warszawa 2005, s. 102.

5 J. Nawój, Budowanie polskiego modelu oddziaływania na przestępców seksualnych, „Przegląd Więziennictwa Polskiego” 2006, nr 51, s. 26; K. Pospiszyl, Powrotność do przestępstw seksualnych (ocena ryzyka i sposoby zabezpieczeń), „Przegląd Więziennictwa Polskiego" 2011, nr 32-33, s. 82.

${ }^{6}$ K. Pospiszyl, Powrotność do przestępstw seksualnych..., s. 82. 
w obowiązującym stanie prawnym istnieje szereg rozwiązań normatywnych umożliwiających realizację skutecznej polityki karnej wobec sprawców przestępstw seksualnych. Mają one na celu nie tylko realizację funkcji sprawiedliwości, czy prewencyjnej prawa karnego, lecz także ukierunkowane są na osiągnięcie funkcji profilaktyczno-zabezpieczającej, która sprowadza się do ochrony stosunków społecznych poprzez eliminowanie z życia społecznego sprawców czynów zabronionych (w drodze kar izolacyjnych lub za pomocą środków zabezpieczających) oraz pozbawiania ich pełnienia pewnych funkcji, wykonywania określonych zawodów ${ }^{7}$.

Trudno się zgodzić z takim poglądem, gdyż istniejące dotąd rozwiązania spełniały tylko w niewielkim stopniu pokładane w nich nadzieje.

Zarówno funkcjonująca przez pewien czas w kodeksie karnym tak zwana kastracja chemiczna ${ }^{8}$, jak i obowiązująca ustawa z dnia 22 listopada 2013 roku o postępowaniu wobec osób z zaburzeniami psychicznymi stwarzających zagrożenie życia, zdrowia lub wolności seksualnej innych osób ${ }^{9}$, określana także mianem Lex Trynkiewicz lub ustawą o bestiach, są raczej wyrazem bezradności i braku pomysłów naszego państwa na efektywne monitorowanie zachowań osób skazanych za przestępstwa seksualne, które zasadnie uznaje się za grupę bardzo niebezpieczną ${ }^{10}$. Wprowadzenie obu tych rozwiązań prawnych zostało w dużej mierze wymuszone na ustawodawcy przez zaniepokojoną opinię publiczną. Tak zwana kastracja chemiczna oraz Lex Trynkiewicz były jednak zmianami pozornymi, mającymi uspokoić społeczeństwo i dać chwilę oddechu politykom. Uchwalenie Lex Trynkiewicz było spowodowane między innymi nieroztropnością ustawodawcy, który w ustawie z dnia 7 grudnia 1989 o amnestii ${ }^{11}$ zamienił wspaniałomyślnie karę śmierci Mariu-

${ }^{7}$ A. Sakowicz, Opinia prawna na temat projektu ustawy o przeciwdziałaniu zagrożeniom przestępczością na tle seksualnym i o zmianie niektórych innych ustaw (druk sejmowy nr 189), Biuro Analiz Sejmowych Kancelarii Sejmu, Warszawa, 23 lutego 2016 r., s. 8 .

${ }^{8}$ Zob. K. Dudka, Propozycje kastracji chemicznej sprawców niektórych przestepstw seksualnych a prawo do życia prywatnego i rodzinnego, [w:] Dylematy praw człowieka, red. T. Gardocka, J. Sobczak, Toruń 2008, s. 215-228.

${ }^{9}$ Dz.U. z 2014 r. poz. 24.

10 T. Gardocka, Ł. Majewski, Jak zabezpieczyć społeczeństwo przed groźnymi sprawcami przestępstw seksualnych? Bezradność legislatorów, [w:] Przestępczy seks, red. T. Gardocka et al., Warszawa 2016, s. 102.

11 Art. 5 ust. 1 pkt 2 ustawy z dnia 7 grudnia 1989 roku o amnestii (Dz.U. z 1989 r. Nr 64, poz. 390). 
szowi T. i kilku innym zbrodniarzom na 25 lat pozbawienia wolności. Było to jedynie odsunięcie w czasie bardzo poważnego i oczywistego zagrożenia dla społeczeństwa ${ }^{12}$ na zasadzie „25 lat to bardzo długo, a co się potem stanie, to nie nasz problem"13.

$\mathrm{W}$ art. 22 ustawy o postępowaniu wobec osób z zaburzeniami psychicznymi stwarzających zagrożenie życia, zdrowia lub wolności seksualnej innych osób wskazano, że celem nadzoru prewencyjnego jest ograniczenie zagrożenia życia, zdrowia lub wolności seksualnej innych osób ze strony osoby stwarzającej zagrożenie, która nie została umieszczona w zamkniętym ośrodku. Nadzór prewencyjny jest sprawowany przez komendanta powiatowego (miejskiego, rejonowego) policji, na którego obszarze osoba stwarzająca zagrożenie ma miejsce stałego pobytu. Osoba, wobec której zastosowano nadzór prewencyjny, ma obowiązek każdorazowego informowania komendanta policji o zmianie miejsca stałego pobytu, miejsca zatrudnienia, imienia lub nazwiska, a jeżeli komendant tego zażąda, również udzielania informacji o miejscu aktualnego i zamierzonego pobytu oraz o terminach i miejscach wyjazdów.

W art. 23 omawianej ustawy określono, że policja do celów nadzoru prewencyjnego może prowadzić czynności operacyjno-rozpoznawcze dotyczące osoby stwarzającej zagrożenie, a także weryfikować, gromadzić i przetwarzać informacje udzielane przez tę osobę oraz uzyskane w wyniku czynności operacyjnych. Jeżeli weryfikowanie tych informacji napotyka trudności lub jeżeli zachodzi uzasadniona obawa, że osoba, wobec której zastosowano nadzór prewencyjny, czyni przygotowania do popełnienia przestępstwa przeciwko życiu i zdrowiu, zagrożonego karą pozbawienia wolności, której górna granica wynosi co najmniej 5 lat, lub przestępstwa przeciwko wolności seksualnej i obyczajności, sąd może zarządzić kontrolę operacyjną. Ustawa zakreśla szerszy katalog przesłanek, w których obliczu zaistnienia można ją zarządzić wobec osoby objętej nadzorem prewencyjnym niż w przypadku kontroli operacyjnej realizowanej na podstawie ustawy o Policji. Nie wiadomo jednak dokładnie, o jakie informacje miałoby chodzić. Nie wiadomo też, czym są w istocie trudności w weryfikowaniu bliżej niesprecyzowanych informacji. Wobec tego ten środek, bardzo inge-

12 Odmiennie P. Waszkiewicz, Traktat o dobrej prewencji kryminalnej, Warszawa-Newark 2015, s. 19-20.

13 T. Gardocka, Ł. Majewski, op. cit., s. 106. 
rujący w sferę wolności danej osoby, może być stosowany nie tylko, gdy istnieją obiektywne trudności wywołane zachowaniem osoby objętej nadzorem, ale przede wszystkim gdy jest to wygodne dla organów ścigania. Co więcej, pomimo pewnych ograniczeń związanych ze stosowaniem kontroli operacyjnej w praktyce może ona trwać w zasadzie dożywotnio ${ }^{14}$.

\section{Czynności operacyjno-rozpoznawcze w systemie monitorowania osób skazanych za przestępstwa na tle seksualnym}

Przydatność czynności operacyjno-rozpoznawczych do monitorowania zachowań przestępców seksualnych jest niestety $z$ kilku powodów ograniczona. Przede wszystkim dlatego, że tylko niewielki odsetek sprawców seksualnego wykorzystania dzieci i dorosłych to osoby zupełnie obce dla ofiar. Wynika to z badań amerykańskich ${ }^{15}$, ale znajduje także potwierdzenie w polskiej praktyce śledczej. Mamy więc najczęściej do czynienia ze sprawcami wywodzącymi się z bezpośredniego otoczenia ofiary. W wielu sytuacjach żadna ze stron nie jest zainteresowana, oczywiście z zupełnie innych powodów, przekazaniem innym osobom informacji o zaistniałym przestępstwie.

Z kolei przestępcy seksualni, którzy nie byli znani swoim ofiarom, podejmują daleko idące działania służące kamuflowaniu ich aktywności. Przestępstwa seksualne popełniane przez takie osoby nie wymagają też najczęściej udziału lub współpracy z innymi osobami, co bardzo utrudnia znalezienie operacyjnego dotarcia do figurantów ${ }^{16}$. Nie kontaktują się

${ }^{14}$ Zob. szerzej D. Szumiło-Kulczycka, Nadzór prewencyjny sprawców niebezpiecznych po odbyciu kary, [w:] Przestępstwa seksualne. Ujęcie psychologiczne, prawne $i$ kryminalistyczne, red. P. Herbowski et al., Warszawa 2016, s. 55-58.

${ }^{15} \mathrm{~S}$. Olson, Reimagining a lifetime of punishment: Moving the sex offender registry to a risk of re-offense model, „Oregon Law Review” 96, 2017, nr 1, s. 325.

16 Zgodnie z $\$ 1$ zarządzenia nr pf-634 KGP z dnia 30 czerwca 2006 roku w sprawie metod i form wykonywania przez policję czynności operacyjno-rozpoznawczych figurantem sprawy operacyjnej jest osoba, wobec której są podejmowane przez policję czynności operacyjno-rozpoznawcze. Rozdział 1 tego zarządzenia, zawierający między innymi definicje podstawowych pojęć, ma charakter jawny; zarządzenie nr pf-1292/08 KGP z dnia 19 grudnia 2008 roku zmieniające zarządzenie w sprawie metod i form wy- 
też zazwyczaj z innymi osobami, na przykład przekazując im informacje dotyczące popełnionych przez siebie czynów. Nie jest to w większości wypadków działalność o charakterze zorganizowanym, poza siatkami pedofilskimi, ale tacy przestępcy nie będą rozpracowywani przez funkcjonariuszy z komend powiatowych policji.

Istnieje wiele form pracy operacyjnej, z których korzystają policjan$\mathrm{ci}^{17}$. Zobrazować to można na przykładzie kilku podstawowych:

- wywiad operacyjny, czyli niejawne zbieranie informacji o interesujących organ operacyjny podmiotach, najczęściej przez prowadzenie odpowiednio ukierunkowanych i planowanych rozmów. Efektywność takiego wywiadu jest znikoma, gdyż na przykład sąsiedzi osób skazanych za przestępstwa seksualne nie mają najczęściej wartościowych informacji na temat ich działalności przestępczej;

— obserwacja — powinna być realizowana przez wyspecjalizowane komórki organizacyjne wydziałów techniki operacyjnej komend wojewódzkich policji. W praktyce funkcjonariusze z komend powiatowych policji korzystają z ich pomocy bardzo rzadko. Niejednokrotnie jednak nawet profesjonalna obserwacja w niewielkim stopniu przyczynia się do poszerzenia wiedzy operacyjnej. Z kolei samodzielne prowadzenie obserwacji przez funkcjonariusza operacyjnego grozi jego szybką dekonspiracją i z reguły niweczy możliwość pozyskania wartościowych informacji na temat zachowania i kontaktów figuranta;

— współpraca $\mathrm{z}$ informatorami — jest to niewątpliwie najważniejsza forma pracy operacyjnej ${ }^{18}$, której trafnie przyznaje się rolę konstytuującą dla określenia istoty niejawnych działań podejmowanych przez organy państwowe realizujące swoje działania w sferze bezpieczeństwa publicznego ${ }^{19}$. Jak już wskazano, niezwykle skryty sposób działania

konywania przez policję czynności operacyjno-rozpoznawczych, niepubl.; zarządzenie nr pf-671/11 KGP z dnia 7 czerwca 2011 roku zmieniające zarządzenie w sprawie metod i form wykonywania przez policję czynności operacyjno- rozpoznawczych, niepubl.

17 Zob. M. Chrabkowski, Metody pracy operacyjnej, [w:] Przestępczość zorganizowana. Fenomen. Wspótczesne zagrożenie. Zwalczanie. Ujęcie praktyczne, red. W. Jasiński, W. Mądrzejowski, K. Wiciak, Szczytno 2013, s. 511.

${ }^{18}$ P. Herbowski, Poufne osobowe źródła informacji. Aspekty kryminalistyczne i prawnodowodowe, Warszawa 2018, s. 9.

${ }^{19} \mathrm{~S}$. Zalewski, Czynności operacyjno-rozpoznawcze jako forma realizacji zadań stużb specjalnych $w$ systemie bezpieczeństwa państwa, „Przegląd Policyjny” 2002, nr 3-4, s. 132. 
przestępców seksualnych bardzo ogranicza możliwości takiego pozyskania informacji;

— kontrola operacyjna — może polegać między innymi na uzyskiwaniu i utrwalaniu treści rozmów prowadzonych z użyciem środków technicznych. W wypadku przestępczości na tle seksualnym nie istnieje zagrożenie odmową jej zastosowania, gdyż jak wykazała D. Szumiło-Kulczycka:

sądy zdają się bezradne w zetknięciu z przedłożonym im materiałem operacyjnym, na podstawie którego mają podjąć decyzję o zarządzeniu lub o odmowie zarządzenia kontroli operacyjnej. Sędziowie nie mają narzędzi do jego merytorycznej oceny, a przede wszystkim narzędzi do jego skutecznej weryfikacji. W efekcie sądy niejako automatycznie uznają za prawdziwe i przekonujące materiały przedłożone przez podmiot ubiegający się o zastosowanie kontroli operacyjnej i wydają decyzję o uwzględnieniu wniosku ${ }^{20}$.

Potwierdził to także w jednym ze swoich wyroków Trybunał Konstytucyjny ${ }^{21}$. Kontrola operacyjna, podobnie jak obserwacja, ma jednak charakter pasywny i powinna służyć przede wszystkim weryfikowaniu i uzupełnianiu informacji uzyskanych od informatorów. Poza tym trudno oczekiwać, by przestępca seksualny chwalił się swoją działalnością na przykład w rozmowie telefonicznej.

\section{Rejestr Sprawców Przestępstw na Tle Seksualnym}

Od pewnego czasu w polskim porządku prawnym funkcjonuje Rejestr Sprawców Przestępstw na Tle Seksualnym, który jest wzorowany na podobnych rejestrach istniejących w krajach anglosaskich - USA, Kanadzie, Australii, Nowej Zelandii oraz Wielkiej Brytanii. Służą one informowaniu społeczeństwa o zagrożeniu, nadzorowi nad sprawcą po wyjściu na wolność oraz prowadzeniu procedury weryfikacji osób starających się o pracę w placówkach edukacyjnych. Odmiennym podejściem wobec omawianej kategorii przestępców jest model pracy terapeutycznej, w którym kluczowym elementem jest terapia sprawców w toku odbywania przez nich kary oraz po opuszczeniu zakładu karnego. Stosuje się go na przykład w państwach skandynawskich, Holandii, Danii, Niemczech oraz we Wło-

20 D. Szumiło-Kulczycka, Korzystanie w postępowaniu karnym przez sądy pierwszej instancji z informacji zebranych operacyjnie, Warszawa 2014, s. 43.

21 Wyrok z dnia 12 grudnia 2005 roku, sygn. akt K 32/04, http://ipo.trybunal.gov.pl/ ipo/Sprawa?\&pokaz=dokumenty\&sygnatura=K\%2032/04 (dostęp: 20.12.2019).

Nowa Kodyfikacja Prawa Karnego 55, 2020

(C) for this edition by CNS 
szech $^{22}$. Jednak doświadczenia związane z tym drugim modelem wskazują raczej nieskuteczność pracy terapeutycznej z przestępcami seksualnymi ${ }^{23}$.

W polskiej ustawie o przeciwdziałaniu zagrożeniom przestępczością na tle seksualnym podkreślono, że szczególnymi środkami ochrony są:

- Rejestr Sprawców Przestępstw na Tle Seksualnym;

- obowiązki pracodawców i innych organizatorów w zakresie działalności związanej z wychowaniem, edukacją, wypoczynkiem, leczeniem małoletnich lub opieki nad nimi;

— określenie miejsc szczególnego zagrożenia przestępczością na tle seksualnym.

$\mathrm{W}$ art. 11 tej ustawy, podobnie jak w ustawie o postępowaniu wobec osób z zaburzeniami psychicznymi stwarzających zagrożenie życia, zdrowia lub wolności seksualnej innych osób, określono, że osoba, której dane zostały zamieszczone w Rejestrze, przebywająca na wolności jest obowiązana do:

- zgłoszenia faktycznego adresu pobytu w jednostce organizacyjnej policji właściwej ze względu na miejsce tego pobytu;

— zgłaszania każdorazowej zmiany faktycznego adresu pobytu, najpóźniej w trzecim dniu tego pobytu, w jednostce organizacyjnej policji właściwej ze względu na miejsce tego pobytu.

Jakie narzędzia przewidziano wobec tego w ustawie o przeciwdziałaniu zagrożeniom przestępczością na tle seksualnym celem weryfikacji przekazanych danych a tym samym monitorowaniu sprawców przestępstw na tle seksualnym? Analiza pozwala na stwierdzenie, że żadnych, a jedynie obwarowano ten obowiązek przepisem karnym w art. 23. Policja może oczywiście podjąć czynności operacyjne, których ograniczenia wcześniej przedstawiono, ale ustawa nie nakłada takiego obowiązku.

\section{Ocena funkcjonowania rejestrów przestępców seksualnych w Stanach Zjednoczonych}

Rejestry przestępców seksualnych powstały w Stanach Zjednoczonych już w latach trzydziestych ubiegłego wieku. Widziano w nich

22 A. Sakowicz, op. cit., s. 9.

23 A. Strzelec, op. cit., s. 59. 
środek prewencji indywidualnej i generalnej oraz narzędzie ułatwiające ujęcie sprawców takich czynów. Wartość rejestrów w zakresie prewencji miała polegać na odstraszaniu od popełniania przestępstw zarówno osób już nimi objętych, jak i potencjalnych sprawców. Przyjmuje się, że przestępcom figurującym w rejestrach trudniej będzie popełnić kolejny czyn kryminalny, gdy będą mieli świadomość, że są stale monitorowani ${ }^{24}$. Rejestry przestępców seksualnych określa się też jako „system monitorowania i śledzenia przestępców seksualnych, którzy wyszli na wolność" 25 . Powszechna dostępność rejestrów ma pomagać społeczeństwu w podejmowaniu odpowiednich środków ostrożności ${ }^{26}$.

Słusznie uznaje się, że ocena efektów funkcjonowania rejestrów w Stanach Zjednoczonych jest trudnym zadaniem, gdyż o poziomie przestępczości seksualnej decyduje wiele czynników, a prawo stanowe jest bardzo niejednolite ${ }^{27}$.

W społeczeństwie amerykańskim przeważają pozytywne oceny rejestrów, gdyż postrzegane są one jako efektywne instrumenty służące zwalczaniu przestępczości seksualnej. Pewnym zaskoczeniem może być natomiast krytyczne podejście do nich osób zajmujących się leczeniem i resocjalizacją przestępców seksualnych, urzędników obsługujących rejestry a także większości przedstawicieli amerykańskiej doktryny prawniczej $^{28}$. Może to wynikać ze świadomości tego, że użyteczność rejestrów dla organów ścigania i społeczeństwa ogranicza niekompletność i nieaktualność zawartych w nich danych. W szczególności odnosi się to do miejsca zamieszkania przestępców seksualnych ${ }^{29}$.

Jak pokazują doświadczenia amerykańskie, umieszczanie na wiele lat w rejestrach prawie wszystkich przestępców seksualnych nie przynosi

24 G. Maroń, Instytucja rejestru przestępców seksualnych w porządku prawnym Stanów Zjednoczonych, „Prokuratura i Prawo” 2019, nr 4, s. 22-24.

25 Sex Offender Registration and Notification Act (SORNA), https://www.justice.gov/criminal-ceos/sex-offender-registration-and-notification-act-sorna (dostęp: 23.12.2019).

26 S. Olson, op. cit., s. 316.

27 Zob. szerzej G. Maroń, op. cit., s. 40-41.

28 D.P. Connor, R. Tewksbury, Public and professional views of sex offender registration and notification, „Criminology, Criminal Justice, Law \& Society” 18, 2017, nr 1, s. $2-7$.

29 G. Maroń, op. cit., s. 43. 
spodziewanych efektów. W głównej mierze powinni się w nich znaleźć sprawcy najcięższych przestępstw oraz recydywiści. Istnienie takich rejestrów jest jednak z pewnością krokiem we właściwym kierunku, ale nie wystarczy, gdyż odpowiedni nacisk powinno się też kłaść na rozwój innych instrumentów służących monitorowaniu przestępców seksualnych, jak na przykład badań poligraficznych.

\section{Badania poligraficzne w systemie monitorowania osób skazanych za przestępstwa seksualne}

Obecnie brakuje w Polsce systemowych rozwiązań, które pozwalałyby efektywnie monitorować zachowania osób skazanych za przestępstwa seksualne. Wydaje się, że wprowadzenie okresowych badań poligraficznych tych osób służyłoby właśnie temu celowi. Podniosłoby też ocenę istniejących rozwiązań w oczach opinii publicznej, a pośrednio przyczyniłoby się też do wzrostu społecznego zaufania do organów ścigania i wymiaru sprawiedliwości. O takim wykorzystaniu badań poligraficznych mówi się w Polsce od ponad dziesięciu lat i w piśmiennictwie można znaleźć wiele artykułów poświęconych temu zagadnieniu ${ }^{30}$.

30 Zob. m.in. M. Gołaszewski, Użyteczność badań poligraficznych w ograniczaniu recydywy wśród sprawców przestęstw przeciwko wolności seksualnej, „Prokuratura i Prawo" 2016, nr 12, s. 5-22; P. Herbowski, D. Słapczyńska, Rola i miejsce badań poligraficznych $w$ procesie monitorowania zachowań osób skazanych za przestepstwa seksualne, [w:] Kierunki zmian organizacyjno-technicznych w Stużbie Więziennej, red. A. Misiuk, M. Kalaman, Warszawa 2016, s. 84-92; A. Leszczyńska, Badania poligraficzne $w$ nadzorze osób skazanych za przestęstwa przeciwko wolności seksualnej, „Probacja” 2014, nr 2, s. 65-72; eadem, Użyteczność badań poligraficznych $w$ terapii i kontroli osób skazanych za przestęstwa przeciwko wolności seksualnej, „Seksuologia Polska” 11, 2013, nr 2, s. 48-55; A. Leszczyńska, A.P. Szajna, Psychofizjologiczne badania poligraficzne (wariograficzne) $w$ leczeniu $i$ nadzorze osób popetniajacych przestepstwa seksualne w Wielkiej Brytania, „Probacja” 2017, nr 3, s. 5-18; M. Leśniak, Problematyka wykorzystania badań poligraficznych wobec osób skazanych poddanych próbie, [w:] Przestępstwa seksualne. Ujęcie psychologiczne..., s. 60-69; M. Skorecki, Poligraf (wariograf) jako instrument wspomagajacy proces resocjalizacji osób skazanych za przestęstwa na tle seksualnym, [w:] Kryminalistyka i inne nauki pomostowe w postępowaniu karnym, red. J. Kasprzak, B. Młodziejowski, Olsztyn 2009, s. 693-705; D. Słapczyńska, Znaczenie badań poligraficznych $w$ resocjalizacji sprawców przestepstw seksualnych, [w:] Przestępstwa seksualne. Ujęcie psychologiczne..., s. 70-80. 
Celem badań poligraficznych w postulowanej formie jest kontrola występowania ryzykownych zachowań wśród skazanych i odstraszenie ich od popełniania kolejnych czynów oraz dostarczenie policji informacji, które należałoby pogłębić w drodze czynności operacyjnych lub procesowych. Taka jest bowiem podstawowa rola badań poligraficznych, które mają charakter screeningowy, stanowiąc rodzaj sita odsiewającego osoby nienaruszające porządku prawnego od tych, na których powinna się skupić uwaga organów ścigania, a więc przede wszystkim funkcjonariuszy z komend powiatowych i miejskich policji. W ramach czynności badawczych można podjęć próbę zweryfikowania następujących kwestii: czy w najbliższym otoczeniu sprawcy znajdują się osoby poniżej 15. roku życia, czy pozostaje on w kontakcie z taką osobą za pośrednictwem internetu, czy i z jaką częstotliwością ma styczność z pornografią, a także czy dopuścił się nieujawnionego dotąd przestępstwa.

Aby implementacja tych badań do takiego systemu była możliwa, kluczowe jest uzyskanie odpowiedzi na następujące pytania:

- Dlaczego badania poligraficzne a nie inne narzędzia?

- Kto ma prowadzić badania poligraficzne?

- Kto ma za to płacić?

- Jaka powinna być podstawa prawna takich badań poligraficznych?

Brak odpowiedzi na te pytania spowodował, że badań poligraficznych nie prowadzi się $\mathrm{w}$ Polsce $\mathrm{w}$ tym zakresie. Niektóre dotychczasowe propozycje nie liczyły się z polskimi realiami finansowymi i miały charakter raczej pobożnych życzeń. Najlepszym tego przykładem jest zestawienie wymogów i kosztów takich badań przedstawione przez jednego z autorów:

- program pilotażowy w wybranym ośrodku ambulatoryjnym;

— przygotowanie pracowni badań poligraficznych w kilku ośrodkach leczenia. Szacunkowe koszty zakupu sprzętu wynoszą 30 tys. zł, a dostosowanie pomieszczenia do prowadzenia badań — około 20 tys. zł;

— szkolenie kadry badającej — koszt szkolenia jednej osoby w USA wynosi około 6000 USD plus koszty logistyczne. W Polsce byłoby to 10-15 tys. zł w zależności od liczebności grupy;

- wybór sposobu wynagradzania ekspertów jest możliwy w dwóch wariantach;

- modelowym rozwiązaniem byłby Państwowy Instytut Badań Psychofizjologicznych z funkcjami szkoleniowymi, naukowo-badawczymi 
i kontrolnymi — na wzór Narodowego Centrum Oceny Wiarygodności w $\mathrm{USA}^{31}$.

Wszystkich wskazanych kosztów nie musi ponosić polskie państwo, gdyż polska policja w swoich laboratoriach kryminalistycznych komend wojewódzkich policji zatrudnia grupę wyszkolonych poligraferów, którzy mogliby z powodzeniem realizować takie badania w ramach swoich obowiązków służbowych. Przemawia za tym też to, że nie są oni nadmiernie obciążeni badaniami poligraficznymi w sprawach kryminalnych, nad czym należy ubolewać. Daje to jednak możliwość ich dalszego doskonalenia w zakresie badań poligraficznych, a nie jak obecnie, gdy są niejednokrotnie biegłymi w kilku specjalnościach, co stwarza niewątpliwie zagrożenie odnośnie do spełniania przez nich najwyższych standardów opiniowania w każdej z tych specjalności. Nie trzeba więc dodatkowo płacić poligraferom, kupować sprzętu do badań, dostosowywać pomieszczeń do prowadzenia badań czy też tworzyć specjalnego instytutu.

Uważamy za zasadne wpisanie do ustawy o przeciwdziałaniu zagrożeniom przestępczością na tle seksualnym, która wprowadziła do polskiego porządku prawnego rejestr takich sprawców, obowiązku okresowego - na przykład co sześć miesięcy lub raz w roku — poddawania się badaniom poligraficznym przez sprawców najpoważniejszych przestępstw seksualnych.

Czy próba zabezpieczenia społeczeństwa przez prawodawcę przed sprawcami przestępstw na tle seksualnym poprzez poddawanie ich okresowym badaniom poligraficznym mogłaby zostać uznana za istotne naruszenie konstytucyjnych praw i wolności? Zdecydowanie nie, gdyż byłoby to uprawnienie nieporównanie mniej ingerujące w te prawa i wolności niż umieszczenie w Rejestrze Sprawców lub długotrwała kontrola operacyjna.

\section{Podsumowanie}

Który model monitorowania przestępców seksualnych wybierzemy? Czy model pracy terapeutycznej połączony z badaniami poligraficznymi (w postaci triady poligrafer-kurator-terapeuta) funkcjonujący w wielu stanach USA, który jednak ze względu na koszty ponoszone częściowo

31 Zob. szerzej M. Gołaszewski, op. cit., s. 17-18. 
przez przestępców oraz inne uwarunkowania prawne jest mało realny w polskich warunkach, czy też znajdziemy własny model pozyskiwania informacji, w którym główne zadania w tym zakresie spoczywałyby na policji? W istocie obecnie tak jest, tyle że zestaw instrumentów, którymi dysponuje ta służba, jest bardzo ograniczony. Badania poligraficzne powinny być uznane za szczególny środek ochrony przed przestępcami seksualnymi i w taki sposób ujęte w ustawie o przeciwdziałaniu zagrożeniom przestępczością na tle seksualnym oprócz Rejestru Sprawców. Nie trzeba byłoby tworzyć rozbudowanego systemu, który często zbyt entuzjastycznie przedstawiają w swoich publikacjach niektórzy autorzy. Należy uznać, że realnych szans na system zbliżony w swoich założeniach do tego amerykańskiego nie ma, a proponowane przez nas rozwiązanie mogłoby być efektywne, ale również tanie, co dla wielu decydentów może mieć bardzo istotne znaczenie.

\section{Bibliografia}

Chrabkowski M., Metody pracy operacyjnej, [w:] Przestępczość zorganizowana. Fenomen. Wspótczesne zagrożenie. Zwalczanie. Ujęcie praktyczne, red. W. Jasiński, W. Mądrzejowski, K. Wiciak, Szczytno 2013.

Connor D.P., Tewksbury R., Public and professional views of sex offender registration and notification, „Criminology, Criminal Justice, Law \& Society” 18, 2017, nr 1.

Dudka K., Propozycje kastracji chemicznej sprawców niektórych przestępstw seksualnych a prawo do życia prywatnego i rodzinnego, [w:] Dylematy praw czlowieka, red. T. Gardocka, J. Sobczak, Torun 2008.

Gardocka T., Majewski Ł., Jak zabezpieczyć spoleczeństwo przed groźnymi sprawcami przestępstw seksualnych? Bezradność legislatorów, [w:] Przestępczy seks, red. T. Gardocka, P. Herbowski, D. Jagiełło, P. Jóźwiak, Warszawa 2016.

Gierowski J.K., Uwagi psychologa sadowego o nowych regulacjach prawnych w sprawach o tzw. przestęstwa seksualne, „Psychiatria Polska” 46, 2012, nr 1.

Gołaszewski M., Użyteczność badań poligraficznych $w$ ograniczaniu recydywy wśród sprawców przestępstw przeciwko wolności seksualnej, „Prokuratura i Prawo” 2016, nr 12.

Herbowski P., Poufne osobowe źródla informacji. Aspekty kryminalistyczne i prawnodowodowe, Warszawa 2018.

Herbowski P., Słapczyńska D., Rola i miejsce badań poligraficznych w procesie monitorowania zachowań osób skazanych za przestępstwa seksualne, [w:] Kierunki zmian organizacyjno-technicznych w Stużbie Więziennej, red. A. Misiuk, M. Kalaman, Warszawa 2016. 
Leszczyńska A., Badania poligraficzne w nadzorze osób skazanych za przestęstwa przeciwko wolności seksualnej, „Probacja” 2014, nr 2.

Leszczyńska A., Użyteczność badań poligraficznych w terapii i kontroli osób skazanych za przestęstwa przeciwko wolności seksualnej, „Seksuologia Polska” 11, 2013, $\mathrm{nr} 2$.

Leszczyńska A., Szajna A.P., Psychofizjologiczne badania poligraficzne (wariograficzne) w leczeniu i nadzorze osób popetniających przestępstwa seksualne w Wielkiej Brytania, „Probacja” 2017, nr 3.

Leśniak M., Problematyka wykorzystania badań poligraficznych wobec osób skazanych poddanych próbie, [w:] Przestępstwa seksualne. Ujęcie psychologiczne, prawne i kryminalistyczne, red. P. Herbowski, W. Krawczyk, D. Słapczyńska, A. Zalewska, Warszawa 2016.

Maroń G., Instytucja rejestru przestępców seksualnych w porządku prawnym Stanów Zjednoczonych, „Prokuratura i Prawo” 2019, nr 4.

Nawój J., Budowanie polskiego modelu oddzialywania na przestępców seksualnych, „Przegląd Więziennictwa Polskiego" 2006, nr 51.

Olson S., Reimagining a lifetime of punishment: Moving the sex offender registry to a risk of re-offense model, „Oregon Law Review” 96, 2017, nr 1.

Pospiszyl K., Powrotność do przestępstw seksualnych (ocena ryzyka i sposoby zabezpieczeń), „Przegląd Więziennictwa Polskiego” 2011, nr 32-33.

Pospiszyl K., Przestęstwa seksualne. Geneza, postacie, resocjalizacja oraz zabezpieczenia przed powrotnościa, Warszawa 2005.

Sakowicz A., Opinia prawna na temat projektu ustawy o przeciwdziałaniu zagrożeniom przestępczościa na tle seksualnym i o zmianie niektórych innych ustaw (druk sejmowy $n r$ 189), Biuro Analiz Sejmowych Kancelarii Sejmu, Warszawa, 23 lutego $2016 \mathrm{r}$.

Skorecki M., Poligraf (wariograf) jako instrument wspomagajacy proces resocjalizacji osób skazanych za przestępstwa na tle seksualnym, [w:] Kryminalistyka i inne nauki pomostowe w postępowaniu karnym, red. J. Kasprzak, B. Młodziejowski, Olsztyn 2009.

Słapczyńska D., Znaczenie badań poligraficznych w resocjalizacji sprawców przestępstw seksualnych, [w:] Przestępstwa seksualne. Ujęcie psychologiczne, prawne i kryminalistyczne, red. P. Herbowski, W. Krawczyk, D. Słapczyńska, A. Zalewska, Warszawa 2016.

Strzelec A., Przymusowe leczenie sprawców czynów zabronionych popetnionych w związku z zaburzeniami preferencji seksualnych, [w:] Konteksty prawa i praw czlowieka, red. Z.M. Dymińska, Kraków 2012.

Szumiło-Kulczycka D., Korzystanie w postępowaniu karnym przez sady pierwszej instancji z informacji zebranych operacyjnie, Warszawa 2014.

Szumiło-Kulczycka D., Nadzór prewencyjny sprawców niebezpiecznych po odbyciu kary, [w:] Przestępstwa seksualne. Ujęcie psychologiczne, prawne i kryminalistyczne, red. P. Herbowski, W. Krawczyk, D. Słapczyńska, A. Zalewska, Warszawa 2016. Waszkiewicz P., Traktat o dobrej prewencji kryminalnej, Warszawa-Newark 2015. 
Zalewski S., Czynności operacyjno-rozpoznawcze jako forma realizacji zadań stużb specjalnych $w$ systemie bezpieczeństwa państwa, „Przegląd Policyjny” 2002, nr 3-4.

\title{
Monitoring the behavior of persons convicted of sexual offenses
}

\begin{abstract}
Summary
In Poland there is a lack of effective solutions to monitor people convicted of sexual offenses. Operational activities also have a limited effectiveness. Therefore, it is advisable to conduct periodic polygraph examinations of the most dangerous perpetrators of such crimes. These examinations should be considered as a special protection measure, similar to the register of sex offenders.
\end{abstract}

Keywords: sex offenders, operational activities, polygraph examinations. 